Thanh Thủy (2003). Phẫu thuâat cắt Amiđan: nhân xét 3962 trường hợp tại viện tai mũi họng. Nôi san Tai mũi họng 2003

3. Springer-Verlag Berlin Heidelberg (2014) Mortality after tonsil surgery, a population study, covering eight years and 82,527 operations in Sweden

4. Hoàng Anh (2015). Đánh gia kết quả phẫu thuât cắt amiđan bằng dao plasma tại khoa Tai Mũi Họng bệnh viện Đại học Y Hà Nội. Đại học Y Hà Nội.

5. Pham Anh Tuấn (2017). Đ̇ánh giá kết quả cắt amiđan bằng dao điện, coblator và plasma. Luận văn thạc sỹ y học, Đại học Y Hà Nội.
6. Võ Hoài Nam (2016). Nghiên cứu đặc điểm lâm sàng, cận lâm sang và các yếu tố nguy cơ của hội chứng ngừng thở lúc ngủ do tắc nghẽn. Đại học y Hà Nội,

7. Nguyến Tuấn Sơn (2012). Nghiên cứu chỉ đinh và đanh giá kết quả điều trị của phương pháp cắt amiđan bằng dao điện đơn cực. Đại học Y Hà Nội.

8. Nguyến Thanh Thủy (2004). Nhân xét về tình hinh chảy máu sau căt Amiđan tại bệnh viện Tai mũi hong Trung ương từ 2001-2003. Đai hoc Y Hà Nội.

9. Jonhson, Rosen (2015) Bailey's Head and neck surgery Otolaryngology. $5^{\text {th }}$ Edition

\title{
KẾT QUẢ PHẪU THUÂTT UNG THƯ TUYẾN NƯớC BỌT CHÍNH TẠI BÊ̂NH VIỆN K
}

\author{
Nguyễn Huy Phan', Ngô Quốc Duy², \\ Ngô Xuân Quý ${ }^{2}$, Lê Chính Đại ${ }^{1}$
}

\section{TÓM TẮT}

Mục tiêu: Nhận xét một số đặc điểm lâm sàng, cận lậm sàng và đánh giá kết quả sớm của phẫu thuật ung thư tuyến nước bọt chính tại bệnh viện $K$. Đối tượng nghiên cứu: Bao gồm 66̆bênh nhân (BN) ung thưtuyến nước bọt chính được chấn đoán và điêu trị phẫu thuật tại bệnh viện $\mathrm{K}$ trong thời gian từ T1/2016- T12/2020. Phương pháp nghiên cứu: Nghiên cứu mô tả lâm sàng hồi cứu kết hợp tiến cứu. Kết quả: Tuổi trung bình 50,3; nam/ nữ: 1,06/1; phát hiện u tại tuyến hay gặp nhất $86,4 \%$; phân trăm tuyễn mang tai, tuyến dưới hàm, tuyến dưới lưỡi: 77,3\%/16,7\%/6\%; một u 98,5\%; kích thước 2-4cm $54,5 \%$; mật độ chắc $90,9 \%$; giảm âm $86,4 \%$; mô bệnh học: ung thư biểu mô biêu bì nhầy $40,1 \%$ ung thư dang tuyên nang $15,2 \% ; 100 \%$ cắt toàn bồ tuyến; vét hạch cổ 39,4\%; liệt mặt sau mổ 31,4\%; hội chứng Frey $13,7 \%$; biến chứng khác $<5 \%$; sau 6 tháng 43,8\% trường hợp liệt mặt có hồi phục. Kết luận: Ung thư tuyến nước bọt thường xuất hiên ở độ tuổi trung niên, phát hiện chủ yếu qua biểu hiện sờ thấy $u$, mô bệnh học đa dạng. Phẫu thuật là phương pháp điều trị chính, bên canh đảm bảo diện cắt, bảo tồn thần kinh là một mổi quan tâm hàng đâu, có ảnh hưởng tới chất lượng cuộc sống của BN.

Tư khóa: ung thư tuyến nước bọt, phẫu thuật, biến chứng.

\section{SUMMARY}

\section{RESULTS OF SURGERY IN MAJOR SALIVARY GLAND CANCERS}

Objectives: This study was conducted to report clinicals, subclinicals and evaluate the early results of

\footnotetext{
${ }^{1}$ Trường Đại học Y Hà Nội

²Bênh viên $K$

Chịu trách nhiệm chính: Nguyễn Huy Phan

Email: nguyenhuyphan.hnu@gmail.com

Ngày nhận bài: 20.8.2021

Ngày phản biên khoa hoc: 11.10.2021

Ngày duyệt bài: 22.10.2021
}

treatment of major salivary gland cancers at Vietnam National Cancer Hospital. Patients and methods: A retrospective, descriptive study on 66 patients with major salivary glandcancers were treated in $\mathrm{K}$ hospital from $01 / 2016$ to $12 / 2020$. Results: mean of age 50,3; male/female ratio: 1,06/1; The most common symptom is mass at glands $86,4 \%$; percentage in parotid, submandibular, sublingual: $77,3 \% /$ $16,7 \% / 6 \%$; single tumor $98,5 \%$; tumor size from 2 $4 \mathrm{~cm} 54,5 \%$; firm tumor $90,9 \%$; hypoechoic $86,4 \%$; histopathology: mucoepidermoid carcinoma $40,1 \%$ adenoid cystic carcinoma15,2\%; total parotidectomy, total submandibular resection and total sublingual resection: $100 \%$; selective neck dissection: 39,4\%; facial nerve palsy $31,4 \%$; Frey's syndrome 13,7\%; after 6 months, 43,8\% case with facial nerve palsy were recovered. Conclusions:Salivary gland cancers most commonly occur in older adults, the main clinic symptoms is mass at glands and histopathology is diversity. Surgery is the most important method in treating salivary gland cancers, facial nerve preservation is significant to ensure the pation's quality of life.

Keywords: salivary glands cancer, surgery, complications.

\section{I. ĐẶT VẤN ĐỀ}

Ung thư tuyến nước bọt gồm ung thư các tuyến nước bọt chính: tuyến mang tai, tuyến dưới hàm, tuyến dưới lưỡi và ung thư tuyến nước bọt phụ, trong đó hay gặp nhất là ung thư tuyến mang tai. Đây là loại ung thư ít gặp ở vùng đầu cổ, chiếm khoảng $0,5 \%$ trong tổng số các loại ung thư và chiếm khoảng từ 3-5\% trong ung thư vùng đầu cổ[1].

Phẫu thuất là phương pháp điều trị chủ yếu. Phẫu thuật cần đảm bảo lấy hết $u$, đảm bảo diện cắt âm tính và cân bảo tồn các nhánh thần kinh có liên quan, giúp đảm bảo nguyên tắc ung thư học và nâng cao chất lượng cuộc sống cho $B N$. 
Tuy nhiên hiện nay chưa có nhiều nghiên cứu.Vì vậy, chúng tôi thực hiện nghiên cứu này nhằm mục tiêu: Nhận xét một số đặc điểm lâm sàng, cận lâm sàng và đánh giá kêt quả sớm của phầu thuật ung thư tuyến nước bọt chính tại bệnh viện $K$.

\section{II. ĐỐI TƯợNG VÀ PHƯƠNG PHÁP NGHIÊN CỨU}

2.1 Đối tượng nghiên cứu. Bao gồm $66 \mathrm{BN}$ ung thư tuyến nước bọt chính được chẩn đoán và điều trị phẫu thuật tại bệnh viện $\mathrm{K}$ từ T1/2016 $-\mathrm{T} 12 / 2020$.

\section{Tiêu chuẩn lựa chọn}

- Các BN ung thư tuyến nước bọt chính (tuyến mang tai, tuyến dưới hàm, tuyến dưới lưỡi) được phẫu thuật tại Bệnh viện K.

- Kết quả mô bệnh học là ung thư tuyến nước bọt

- Thể trạng chung tốt: PS từ $0-1$.

- BN chưa được điều trị trước đó.

Tiêu chuân loại trừ

- BN không thỏa mãn bất kì một tiêu chuẩn lựa chọn nêu trên

- Ung thư tái phát hoặc mắc ung thư thứ hai.

- Mắc bệnhmạn tính hoặc cấp tính trầm trọng có nguy cơ tử vong trong thời gian ngắn.

\subsection{Phương pháp nghiên cứu}

Thiết kế nghiên cứu: Nghiên cứu mô tả lâm sàng hồi cứu kết hợp tiến cứu.

Cỡ mẫu: Bằng phương pháp chọn mẫu thuận tiện, nghiên cứu của chúng tôi thu thập được 66́BN thỏa mãn tiêu chuấn lựa chọn và tiểu chuẩn loại trừ.

1.3. Xử lý số liệu. Nhập và xử lý số liệu bằng phần mềm SPSS 20.0.

\section{KẾT QUẢ NGHIÊN CỨU}

\section{1. Đặc điểm lâm sàng}

Tuổi, giới: Tuổi trung bình 50,3 , cao nhất 83 tuổi, thấp nhất 16 tuổi. Tỷ lệ Nam/Nữ là 1,06/1

Lý do vào viện: phát hiện u tại tuyến chiếm $86,4 \%$, số còn lại vào viện do liệt dây VII, hạch cổ và khám sức khỏe định kỳ.

Vị trí: u tuyến mang tai chiếm $77,3 \%$, tuyến dưới hàm chiếm $16,7 \%$ và tuyến dưới lưỡi là $6 \%$.

Kích thước u: nhóm kích thước 2-4cm chiếm
$54,5 \%, 34,8 \%$ BN có u $<2 \mathrm{~cm}$.

Tính chất u: $90,9 \%$ u có mật độ chắc, $62,1 \%$ khối u còn di động, chỉ 1,5\% có biểu hiện thâm nhiễm da.

Tính chất hạch: có 18 BN phát hiện hạch trên lâm sàng, chiếm $27,3 \%$, hầu hết là hạch cùng bên $(77,8 \%)$, mật độ chắc $(83,3 \%)$.

\section{2. Đặc điểm cận lâm sàng}

Bảng 1. Đặc điểm siêu âm

\begin{tabular}{|c|c|c|c|}
\hline & Tính chất & Số BN & Tỷ lệ \% \\
\hline \multirow{2}{*}{$\begin{array}{c}\text { Số } \\
\text { lượng }\end{array}$} & Một khối & 65 & 98,5 \\
\cline { 2 - 4 } & Nhiều hơn 1 khối & 1 & 1,5 \\
\hline \multirow{2}{*}{ Kích } & $<2 \mathrm{~cm}$ & 20 & 30,3 \\
\cline { 2 - 4 } & $2 \mathrm{~cm}-4 \mathrm{~cm}$ & 37 & 51,6 \\
\cline { 2 - 4 } & $>4 \mathrm{~cm}$ & 9 & 13,6 \\
\hline \multirow{2}{*}{$\begin{array}{c}\text { Ranh } \\
\text { giới }\end{array}$} & Rõ & 36 & 54,5 \\
\hline \multirow{2}{*}{ Mật độ } & Không rõ & 30 & 45,5 \\
\cline { 2 - 4 } âm & Giảm âm & 57 & 86,4 \\
\cline { 2 - 4 } & Tăng âm & 3 & 4,5 \\
\hline \multirow{2}{*}{ Hạch } & Hôn hợp âm & 6 & 9,1 \\
\cline { 2 - 4 } & Có & 29 & 43,9 \\
\cline { 2 - 4 } & Không & 37 & 56,1 \\
\hline
\end{tabular}

Nhân xét: khi phát hiệ, hầu hết BN có 1 khối u, chỉ có 1 BN phát hiện nhiều hơn 1 khối, $51,6 \%$ u có kích thước từ $2-4 \mathrm{~cm} ; 86,4 \%$ trường hợp u giảm âm. Có $43,9 \%$ trường hợp phát hiện hạch trên siêu âm, nhiều hơn trên thăm khám lâm sàng.

Bảng 2: Phân loại mô bệnh học

\begin{tabular}{|c|c|c|}
\hline & $\begin{array}{c}\text { Số } \\
\text { BN }\end{array}$ & $\begin{array}{c}\text { Tỷ lệ } \\
\text { \% }\end{array}$ \\
\hline Ung thư biếu mô dạng biếu bì nhây y & 27 & 40,1 \\
\hline Ung thư biếu mô dạng tuyến nang & 10 & 15,2 \\
\hline Ung thư cơ biểu mô & 6 & 9,1 \\
\hline Ung thư biếu mô tế bào vảy & 2 & 3,0 \\
\hline Ung thư biếu mô không biệt hóa & 3 & 4,5 \\
\hline Ung thư biê̂u mô ô̂ng tuyến nước bọt & 3 & 4,5 \\
\hline Ung thư khác & 15 & 22,8 \\
\hline Tống & $\mathbf{6 6}$ & $\mathbf{1 0 0}$ \\
\hline
\end{tabular}

Nhânn xét: UTBM dạng biểu bì nhầy, UTBM dạng tuyến nang là 2 dạng mô bệnh học phổ biến nhất, chiếm $40,1 \%$ và $15,2 \%$.

\subsection{Kết quả điều trị}

Bảng 3: Phương pháp phẫu thuật theo từng tuyến

\begin{tabular}{|c|c|c|c|c|c|c|c|}
\hline \multirow{2}{*}{\multicolumn{2}{|c|}{ 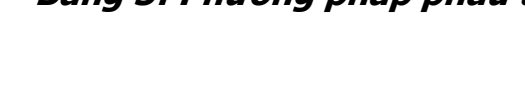 }} & \multicolumn{2}{|c|}{ Tuyến mang taí } & \multicolumn{2}{|c|}{ Tuyến dưới hàm } & \multicolumn{2}{|c|}{ Tuyến dưới lưỡi } \\
\hline & & Số BN & Tỷ lệ \% & Số BN & Tỷ lệ \% & Số BN & Tỷ lệ \% \\
\hline \multirow{2}{*}{$\begin{array}{l}\text { Phầu } \\
\text { thuât }\end{array}$} & Cắt u đơn thuân & $\mathbf{0}$ & 0 & $\mathbf{0}$ & 0 & $\mathbf{0}$ & 0 \\
\hline & Cắt toàn bộ tuyến & 51 & 100 & 11 & 100 & 4 & 100 \\
\hline \multirow{2}{*}{$\begin{array}{c}\text { Vét hach } \\
\text { cố }\end{array}$} & Có & 20 & 39,2 & 4 & 36,4 & 2 & 50 \\
\hline & Không & 31 & 60,8 & 7 & 63,6 & 2 & 50 \\
\hline
\end{tabular}

Nhận xét: Tất cả $\mathrm{BN}$ được cắt toàn bộ tuyến, không có $\mathrm{BN}$ nào cắt u đơn thuân. Tỷ lệ vét hạch cổ của 3 tuyến lần lượt là $39,2 \%, 36,4 \%$ và $50 \%$. Đây đều là các trường hợp phát hiện có hạch qua lâm sàng hoặc siêu âm. 
Bảng 4: Biến chứng sớm sau phẫu thuật

\begin{tabular}{|c|c|c|c|}
\hline Biến chứng & Số BN & Tống số & Tỷ lệ \% \\
\hline Liệt dây VII & 16 & 51 & 31,4 \\
\hline Nhiêm trùng & 0 & 66 & 0 \\
\hline Chảy máu & 1 & 66 & 1,5 \\
\hline Rò nước bọt & 2 & 66 & 3 \\
\hline HC Frey & 7 & 51 & 13,7 \\
\hline
\end{tabular}

Nhận xét: Trong 66BN được phầu thuật, có $2 \mathrm{BN}$ rò nước bọt, 1 ca chảy máu và 0 trường hợp nào bị nhiễm trùng sau mổ.Trong nhóm 51 BN u tuyến mang tai, có 16 BN có liệt mặt sau mổ chiếm $31,4 \%$ (đã loai trừ 7 BN có liệt măt từ trước mổ), 7 BN gặp hội chứng Frey chiếm 13,7\%,

Bảng 5: Biến chứng sau phẫu thuật 6 tháng

\begin{tabular}{|c|c|c|}
\hline Biến chứng & Số BN & Tỷ lệ \% \\
\hline Liệt dây VII & 9 & 17,6 \\
\hline Rò nước bọt & 0 & 0 \\
\hline HC Frey & 7 & 13,7 \\
\hline
\end{tabular}

Nhận xét: Sau 6 tháng theo dõi, có 7 BN liệt mặt tạm thời đã hồi phục, không còn $B N$ nào có tình trạng rò nước bọt. Cả 7 BN gặp hội chứng Frey vẩn tiếp diễn sau 6 tháng.

\section{BÀN LUÂN}

\section{1. Đặc điểm lâm sàng}

Tuổi, giới: Trong nghiên cứu của chúng tôi, tuổi trung bình là 50,3 tuổi. Nhiều nghiên cứu trong và ngoài nước cho thây tuổi trung bình này khác nhau, trong khoảng 40-60 tuổi. Terhaard và cộng sự khi nghiên cứu 498 trường hợp ung thư tuyến nước bọt tại Hà Lan cho thây tuối trung bình là 59, trong khoảng 8-100 tuổi, với tỷ lệ nam/nữ là 1,04/1[2]. Tỷ lệ nam/ nữ cũng khác nhau với nhiều nghiên cứu, theo một nghiên cứu của tác giả Mendenhall có tỷ lệ nam/ nữ là 1,4/1[3].

Lý do vào viện: Đa số $B N$ đến viện do phát hiện khối u tại tuyến, chiếm $86,4 \%$. Tỷ lệ này thấp hơn so với nghiên cứu của tác giả Hàn Thị Vân Thanh (2001) [4].

Vị trí u: Tỷ lệ khối u tuyến mang tai trong nghiển cứu của chúng tôi chiếm $77,3 \%$, tuyến dưới hàm chiếm $16,7 \%$ và tuyến dưới lưỡi là $6 \%$. Kết quả của chúng tôi khá tương đồng với nghiên cứu của Mendenhall (2005), có tỷ lệ này là $85 \%$ tại tuyến mang tai và $15 \%$ tại tuyến dưới hàm[3].

Kích thước u: thường gặp nhất $\mathrm{u}$ trong khoảng 2-4cm, chiếm 54,5\%; 90,9\%u có mật độ chắc.

\section{2. Đặc điểm cận lâm sàng:}

Đặc điểm u trên siêu âm: $98,5 \%$ BN chỉ có 1 khối u, đa phần giảm âm $86,4 \%$, có 29 trường hợp phát hiện hạch trên siêu âm, trong khi lâm sàng phát hiện 18 trường hợp.

Phân loại mô bệnh học: thể mô bệnh học hay gặp nhất là ung thư biểu mô dạng biểu bì nhầy, chiếm 40,1\%, sau đó là ung thư biểu mô dạng tuyến nang chiếm $15,2 \%$. Tỷ lệ này có sự khác biệt so với nghiên cứu của Lombardi (2016) cho kết quả ung thư dang tuyến nang chiếm $26 \%$ và ung thư biểu bì nhâyy chỉ chiếm 17\%[5]. Một nghiên cứu khác của Carlson và cộng sự (2019) khi nghiên cứu $71 \mathrm{BN}$ ung thư tuyến nước bọt đưa ra tỷ lệ ung thư biểu mô biểu bì nhầy là 31\% [6].

\subsection{Kết quả điều trị}

Phương pháp phẫu thuật: Tất cả BN được phẫu thuật cắt toàn bộ tuyển, có hoặc không kèm vét hạch cổ. 26 BN được vét hạch cổ do có hạch nghi ngờ di căn trên lầm sàng và siêu âm. Có 4 trường hợp không được bảo tồn thần kinh do u đã xâm lấn. Tỷ lệ vét hạch cổ trong nghiên cứu của chúng tôi là $39,9 \%$. Tuy nhiên tỷ lệ di căn hạch theo kết quả mô bệnh học sau mổ chỉ chiếm $27,3 \%$. Kết quả này khá tương đồng với nghiên cứu của Stenner (2012) cho thấy tỷ lệ di căn hạch là 21,4\%[7].

Biến chứng sau phẫu thuật:xét riêng trong nhóm u tuyến mang tai và tuyến dưới hàm, sau mổ có $16 / 51$ BN có liệt mặt do mổ (sau khi đã loại trừ 7 tường hợp liệt mặt trước mổ), chiếm $31,4 \%$ và là biến chứng hay gặp nhất, chiếm $57,1 \%$ các biến chứng sau mổ. Tỷ lệ này của chúng tôi tương đương với nghiên cứu của Hàn Thị Vân Thanh, có tỷ lệ liệt mặt 24,7\%[4]. Theo nghiên cứu của Đinh Xuân Thành, tỷ lệ này là 18,2\%[8]. Hội chứng Frey, trong nghiên cứu của chúng tôi, gặp ở $7 / 51$ trường hợp $(13,7 \%)$. Tỷ lệ này tương đồng với nhiều tài liệu được công bố với tỷ lệ xuất hiện hội chứng này là $10 \%[9]$.

Theo dõi biến chứng sau 6 tháng: Có $7 / 16$ bệnh nhân hồi phục sau liệt mặt. Có thể giải thích do dây thần kinh VII bị tổn thương tạm thời trong mổ khi bị kéo, khô, hay do đốt điện; sau một thời gian khi dây thần kinh hồi phục thì các triệu chứng liệt mặt cũng giảm dần và có thể mất hoàn toàn.

\section{KẾT LUÂN}

Đặc điểm lâm sàng, cận lâm sàng. Tuổi mắc bệnh trung bình là 50,3 , tuổi thấp nhất là 16, cao nhất là 83. Tỷ lệ nam/nữ là 1,06/1.

Tỷ lệ u tuyến mang tai, tuyến dưới hàm, tuyến dưới lưỡi lần lượt là $77,3 \%, 16,7 \%$ và $6 \%$. Kích thước $2-4 \mathrm{~cm}$ chiếm $54,5 \%$. Đa số u có mật độ chắc $90,9 \%$.

Trên siêu âm, $98,5 \%$ chỉ có 1 khối u với $86,4 \%$ trường hợp giảm âm. Thể mô bệnh học hay gặp nhất là ung thư biểu mô dạng biểu bì nhây chiếm $40,1 \%$, theo sau là ung thư biểu mô dạng tuyến nang với 15,2\%. 
Kết quả điêuu trị. Tất cả BN được phẫu thuật cắt toàn bộ tuyến. Có 26/66 trường hợp được vét hạch cổ với 18 trường hợp có di căn hạch ở kết quả mô bệnh học sau mổ. Trong nhóm ung thư tuyến mang tai và tuyến dưới hàm, có $16 / 51$ trường hợp liệt mặt sau mổ chiếm 31,4\%; sau 6 tháng theo dối, 7 BN đã hồi phục. 7 BN gặp hội chứng Frey tương đương 13,7\%.

\section{TÀl LIÊU THAM KHẢO}

1. L. v. Quảng (2020). Ung thư đầu cổ, Nhà xuất bản Y học, Hà Nội.

2. C. H. Terhaard, H. Lubsen, C. R. Rasch và cộng sư (2005). The role of radiotherapy in the treatment of malignant salivary gland tumors. Int J Radiat Oncol Biol Phys, 61(1), 103-111.

3. W. M. Mendenhall, C. G. Morris, R. J. Amdur và cô̂ng sự (2005). Radiotherapy alone or combined with surgery for salivary gland carcinoma. Cancer,
103(12), 2544-2550.

4. H. T. V. Thanh (2001). Nhận xét đặc điểm lâm sàng, mô bênh hoc và kết quả phẫu thuât của u tuyến nước bọt mang tai ở bệnh viện $\mathrm{K}$ từ 19962001. Luân văn thac sĩ y hoc, Trường đai hoc Y Hà Nội,

5. D. Lombardi, M. McGurk, V. Vander Poorten và cộng sự (2017). Surgical treatment of salivary malignant tumors. Oral Oncol, 65, 102-113.

6. E. R. Carlson và T. Schlieve (2019). Salivary Gland Malignancies. Oral Maxillofac Surg Clin North Am, 31(1), 125-144.

7. M. Stenner, C. Molls, J. C. Luers và công sự (2012). Occurrence of lymph node metastasis in early-stage parotid gland cancer. Eur Arch Otorhinolaryngol, 269(2), 643-648.

8. Đ. X. Thành (2013). Nghiên cứu chẩn đoán và điều trị phấu thuật u tuyến nước bọt mang tai. Luân án tiến sĩ,

9. H. A. Linder T.E, Schmid S (1997). Frey's syndrome after parotidectomy: a restrospective and prospective analysis. Laaryngoscope, (107), 135-164.

\title{
NHÂ̂N XÉT MộT SỐ ĐĂC ĐIỂM LÂM SÀNG, CÂ̂N LÂM SÀNG VÀ KẾT QUẢ ĐIỀU TRI U ĐỆM DẨY SINH DỤC BUỒNG TRỨNG TẠI BỆNH VIỆN K
}

\author{
Nguyễn Thị Lý Linh ${ }^{1}$, Lê Thanh Đức ${ }^{2}$, Nguyễn Mạnh Tuấn ${ }^{3}$
}

\section{TÓM TẮT}

Mục tiêu: Nhận xét môt số đặc điểm lâm sàng, cận lâm sàng và kết quả điều trị u đệm dây sinh dục buồng trứng tại bệnh viện $K$. Đối tượng và phương pháp nghiên cứu: Nghiên cứu mô tả hồi cứu kết hợp tiến cứu trên 71 bệnh nhân u buồng trứng đã được phẫu thuật và xét nghiệm mô bệnh học tại bệnh viện $\mathrm{K}$, chẩn đoán sau mổ là u đệm dây sinh dục buồng trứng từ tháng 2016 đến 2020. Kêt quả: Độ tuổi trung bình là $51,6 \pm 15,7$ tuổi, thể mô bệnh học gặp nhiêu nhất là $u$ tễ bào hat và nhóm u xơ-vó. Kích thước trung bình của u là $11,6 \mathrm{~cm}$ (từ $3,5 \mathrm{~cm}$ đến $25 \mathrm{~cm}$ ). Bênh giai đoạn I chiếm đa số với $69,2 \%$, giai đoạn II và III lần lượt là $19,2 \%$ và $11,5 \%$. Trung bình thời gian theo dõi là̀ 37,0 tháng (từ 8,6-69,6 tháng), sống thêm toàn bộ (OS) và sống thêm không tái phát (DFS) 5 năm ở nhóm u tế bào hat lần lướt là $83,3 \%$ và $67,7 \%$. Giai đoạn tiến triển và bệnh còn sót lại sau phẫu thuất là yếu tố tiên lượng kém của nhóm bệnh nhân $u$ tế bào hạt $(p<0,05)$. Kết luận: $U$ đệm dây sinh dục là loại u buồng trứng ít gặp với phân bố tuối rộng rã̃i và nhiều dưới nhóm mô bệnh học. U tế bào hạt là thể mô bệnh học ác tính thường gặp nhất, với phần lớn u ở giai đoạn sớm và có tiên lượng tốt. Giai

\footnotetext{
${ }^{1}$ Trường Đại học Y Hà Nội

²Bệnh viện $K$

33Bệnh viện Bệnh nhiệt đới Trung Ương

Chịu trách nhiệm chính: Nguyễn Thị Lý Linh

Email: Iylinh150294@gmail.com

Ngày nhận bài: 18.8.2021

Ngày phản biện khoa họ: 15.10 .2021

Ngày duyệt bài: 22.10 .2021
}

đoạn ban đầu và bệnh còn sót lạilà yếu tố tiên lượng quan trọng của thể mô bệnh học này.

Tư khoá: u đệm dây sinh dục buồng trứng

\section{SUMMARY}

\section{ASSESSMENT CLINICAL FEATURES AND TREATMENT OUTCOME OF OVARIAN SEX CORD-STROMAL TUMORS AT VIETNAM NATIONAL CANCER HOSPITAL \\ Purpose: We aimed to assess the clinical features,} treatment strategy and outcome of ovarian sex cordstromal tumors (SCSTs). Materials and Methods: Medical records of 72 casesdiagnosed SCSTs on from 2016 through 2020 in Vietnam National Cancer Hospital were reviewed retrospectively. Results: patients with mean age of $51.6 \pm 15.7$ were reviewed. The most common subtypes were granulosa cell tumors (GCTs) and thecoma-fibroma groups. The mean diameter of the tumor was $11.6 \mathrm{~cm}$ (range: 3.5$25 \mathrm{~cm}$ ). The majority of ovarian GCTs were diagnosed at anearly stage $(69.2 \%)$ and $19.2 \%$ and $11.5 \%$ for stage II and III, respectively. For a median follow up of 37.0 months (range 8.6-69.6 months), the 5-year overall-survival (OS) and disease-free-survival (DFS) rates were $83.3 \%$ and $67.7 \%$ respectively. Advanced stage and residual tumor werepoor prognosis factors in patient with ovarian GCTs $(p<0.05)$. Conclusion: SCSTs are uncommon ovarian tumors with a wide age range and diverse histological types. The majority malignant subtypesare GCTs which are diagnosed at an early age and have favorable prognosis. Initial stageand residual diseaseare important prognostic factors of this type.

Keywords: ovarian sex cord- stromal tumors, ovarian granulosa cell tumors. 